\title{
Do Migrants Improve Governance at Home? Evidence from a Voting Experiment
}

\author{
Catia Batista and Pedro C. Vicente
}

\begin{abstract}
Can international migration promote better institutions at home by raising the demand for political accountability? A behavioral measure of the population's desire for better governance was designed to examine this question. A postcard was distributed to households promising that if enough postcards were mailed back, results from a survey module on perceived corruption would be published in the national media. Data from a tailored household survey were used to examine the determinants of this behavioral measure of demand for political accountability (undertaking the costly action of mailing the postcard) and to isolate the positive effect of international emigration using localitylevel variation. The estimated effects are robust to the use of instrumental variables, including past migration and macro shocks in the destination countries. The estimated effects can be attributed mainly to migrants who emigrated to countries with better governance, especially migrants who return home. JEL codes: F22, O12, O15, O43, P16

Keywords: international migration, governance, political accountability, institutions, effects of emigration in origin countries, household survey, Cape Verde, sub-Saharan Africa
\end{abstract}

Recent research has examined the importance of international migration to development in countries of origin. The positive effects on economic growth are well documented for international remittances, return migrants, diaspora

Catia Batista (catia.batista@tcd.ie) is assistant professor at Trinity College Dublin and research affiliate at the Institute for the Study of Labor (IZA). Pedro C. Vicente (vicentep@tcd.ie) is assistant professor at Trinity College Dublin, research associate at the Centre for the Study of African Economies (CSAE), University of Oxford, and research affiliate at the Bureau for Research and Economic Analysis of Development (BREAD). The authors gratefully acknowledge useful comments from the journal editor and three anonymous referees. Additional valuable suggestions were provided by Alan Barrett, Michel Beine, Ron Davies, Claudia Martinez, Franco Mariuzzo, John McHale, Kevin O'Rourke, Pia Orrenius, Hillel Rapoport, Frances Ruane, Maurice Schiff, Antonio Spilimbergo, Dean Yang, and participants in a number of seminars and conferences. The authors are indebted to Paul Collier for his initial encouragement of this research project. They thank the dedicated team of local enumerators with whom they worked, and Deolinda Reis and Francisco Rodrigues at the National Statistics Office of Cape Verde. Research assistance was provided by Mauro Caselli. Batista gratefully acknowledges financial support from the George Webb Medley Fund at the University of Oxford. Vicente gratefully acknowledges financial support from the Economic and Social Research Council (ESRC)-funded Global Poverty Research Programme for the household survey conducted in Cape Verde on which this article is based.

THE WORLD BANK ECONOMIC REVIEW, VOL. 25, NO. 1, pp. 77-104

doi:10.1093/wber/lhr009

Advance Access Publication May 12, 2011

(C) The Author 2011. Published by Oxford University Press on behalf of the International Bank for Reconstruction and Development / THE WORLD BANK. All rights reserved. For permissions, please e-mail: journals.permissions@oup.com 
effects promoting foreign investment and international trade, and emigration of the most educated. ${ }^{1}$ Less attention has gone to the influence of international migration on the quality of institutions, which can be crucial to economic development (see Acemoglu, Johnson, and Robinson 2005).

The traditional perspective views emigration as a safety valve that allows individuals unhappy with their political institutions to leave their home country. ${ }^{2}$ Emigration could therefore be detrimental to the domestic political system (a form of "brain drain") by undermining demand for political accountability and, if those who leave are especially qualified to improve political institutions, by weakening the capacity to supply better quality institutions.

Emigration may also promote improved political institutions in several ways: emigrants may create strong diaspora effects influencing political change (for example, by influencing local authorities on the supply side or by exposing the domestic population to better institutions abroad on the demand side). If return emigrants benefited from an enriching experience abroad, that could also translate into improvements in the quality of domestic political institutions (on the supply side by increasing direct participation in the political system and on the demand side by raising awareness and demand for political accountability).

Because emigration could affect political institutions differently depending on the context, what actually happens is an empirical question that remains unanswered in the literature. This article tests the hypothesis that international migration experiences promote better institutions at home by boosting demand for political accountability.

Examining this question requires understanding popular demand for political accountability. A simple voting experiment was used to capture a behavioral measure of demand for better governance at home. Following a survey of perceived corruption in public services, respondents were asked to mail a prestamped postcard if they wanted the (anonymous) results of this survey to be made publicly available in the media. They were told that at least 50 percent of respondents would have to return postcards for the information to be released publically.

1. Evidence of the positive effects of remittances is provided, among others, by Edwards and Ureta (2003) for El Salvador and Yang (2008) for the Philippines. Dustmann and Kirchkamp (2003), Mesnard and Ravallion (2006) and Batista, McIndoe-Calder, and Vicente (2010) examine the role of return migration. Gould (1994), Rauch and Trindade (2002), Kugler and Rapoport (2007), Iranzo and Peri (2009), and Javorcik and others (forthcoming) evaluate the relationship between migrant networks, and trade and foreign investment. The possibility of a "brain gain" as opposed to traditional "brain drain" is empirically supported by Beine, Docquier, and Rapoport (2008) and Batista, Lacuesta, and Vicente (forthcoming).

2. Hirschman (1970) proposed the "exit" vs. "voice" dichotomy by which citizens unhappy with the domestic situation choose either to emigrate (exit) or to protest and contribute to political change (voice). In this setting, emigration may be understood as a "safety valve," which releases protest intensity in the home political system and therefore reduces demand for political improvements. 
This voting experiment was not a randomized controlled trial but simply a way to obtain a behavioral measure of demand for political accountability. This measure is likely superior to standard self-reported measures from survey data, which may suffer from "conformity bias" (respondents may want to conform to the perceived anticorruption message of the survey). This behavioral measure of demand for better institutions is therefore a methodological contribution of this article.

Tailored data from a purposely designed and conducted household survey in Cape Verde is used to examine the determinants of voting behavior and to isolate the positive effect of international emigration on the demand for political accountability. A simple political economy framework takes voting behavior as the outcome of an expected cost-benefit analysis. A detailed survey was customized to control for potentially varying voting costs (such as the distance to post mail and the ease and frequency of doing so) and for characteristics affecting perceived voting benefits (such as confidence in surveyors, income, and family structure). Overall, the results show that international emigration positively affects demand for improved political accountability, with stronger effects for migrants to countries with better governance and for return migrants than for current migrants.

Empirical evidence on the impact of emigration on the quality of political institutions in origin countries is scarce, but there are a few recent contributions. Docquier and others (2010) present cross-country evidence that unskilled emigration from a large sample of developing countries to Organisation for Economic Co-operation and Development countries over 1975-2000 positively affected institutional quality in origin countries (measures of democracy and economic freedom). Though skilled emigration had an ambiguous effect in the short run, simulations found significant institutional gains from "brain drain" over the long run, after considering incentive effects of the brain drain on human capital formation. Li and McHale (2009) describe possible mechanisms through which skilled emigration could affect political and economic institutions at home, presenting cross-country evidence for 1990-2006 consistent with the hypothesis of a positive effect on political institutions (particularly on political accountability) but not on economic institutions. Spilimbergo (2009) uses evidence from 1960 to show that foreign education acquired in democratic countries seems to promote democracy in home countries.

These empirical contributions are consistent with the results reported here, but they cannot distinguish between supply and demand forces nor capture the mechanisms underlying the identified effects because they use aggregate data and explore cross-country variation. This article uses tailored household survey data for a single country, which allows focusing more specifically on the impact of emigration on the demand for improved political accountability, while discriminating between the impact of return and current migrants. This approach relies on within country variation, rather than the traditional 
cross-country source of variation. Reliance on data for a single country may, however, raise external validity concerns, so that contributions by these different lines of work are both important and complementary.

Section I presents an overview of Cape Verde, to provide context for the study. Section II describes the experimental design and theoretical framework supporting the empirical strategy. Section III details the tailored household survey used in the empirical work, including the main descriptive statistics. These data are then used in the empirical analysis reported in section IV. Section V presents some concluding remarks.

\section{An Introduction to Cape Verde}

Cape Verde is an island country off the coast of West Africa whose 441,000 inhabitants live on nine islands. Much of the population is concentrated on Santiago, the largest island and home to the country's capital, Praia (INE 2002). The country is religiously and ethnically homogeneous: the index of religious fractionalization is 7.66 percent $^{3}$ (96 percent of the population is Roman Catholic). The ethnolinguistic fractionalization index is 41.74 percent, comparable to that in Spain and New Zealand and in contrast with high fractionalization indexes of more than 80 percent in 20 Sub-Saharan countries.

Cape Verde won its independence from Portugal in 1975, and a socialist regime took power. The first free elections took place in 1991, and a stable democracy has been in place since then. Governance has been good, particularly for a Sub-Saharan African country: Cape Verde ranked 46 of 180 countries according to Transparency International (2009), slightly behind Botswana and Mauritius. The World Bank's (2011) Worldwide Governance Indicators heralded Cape Verde as having the Best Control of Corruption in Sub-Saharan Africa in 2005, after Botswana.

In economic performance, Cape Verde is ranked as a lower middle-income economy by the World Bank (2006), with a 2003 GDP per capita of $\$ 5,900$ (in purchasing power parity terms; Heston, Summers, and Aten 2006). With an average annual per capita economic growth rate of 4.4 percent over 19812004 (and 5.8 percent over 1991-2000), it has greatly outperformed the Sub-Saharan African average of 0.6 percent, with only Equatorial Guinea (11 percent) and Botswana ( 5 percent) growing faster (Heston, Summers, and Aten 2006). While these countries have exports accounting for 47 percent and 55 percent of GDP and are rich in natural resources, Cape Verde grew despite a much smaller export share of 20 percent and a dearth of natural resources-in fact, Cape Verde has been plagued by droughts and famines.

3. This index is computed as one minus the Herfindahl index of group shares and expresses the probability that two randomly selected individuals from a population belong to different groups. See Alesina and others (2003) for details. 
Those droughts and famines have been closely related to the country's massive emigration. Based on the stock of immigrants in most destination countries, Batista, Lacuesta, and Vicente (forthcoming) estimate that there are around 100,000 Cape Verdean current emigrants, or about 23 percent of the population. Also striking is the magnitude of brain drain emigration: an astonishing 68 percent of the educated labor force of Cape Verde lives abroad (Docquier and Marfouk, 2006). While these results depend on how educational attainment is defined, this is arguably the highest rate in Africa. Finally, international remittances are high, accounting for 16 percent of GDP over 19872003 (World Bank 2006). ${ }^{4}$ Remittances have always surpassed foreign direct investment and have nearly duplicated the amount of foreign aid, particularly since 2000 .

Freedom House (2011) classifies Cape Verde as "among the freest media environments in Africa." According to the Press Freedom Index, Cape Verde ranked 44 of 175 countries in freedom of the press, close to France, Spain, and Argentina (Reporters without Borders 2009).

\section{Experimental Design and Empirical Strategy}

To empirically evaluate the hypothesis that international emigration may promote demand for better governance at home, this study offered respondents to a survey on perceived corruption in public services the opportunity to (anonymously ${ }^{5}$ ) make the results available in the national media by participating in a "special referendum." Following their completion of the corruption questionnaire, respondents were offered the opportunity to vote for political accountability by taking the incentive-compatible voting action of mailing a prepaid postcard that read: "I wish that the conclusions of the survey on the quality of national public services (health, education, justice,...), conducted by the University of Oxford (UK) in the first months of 2006 to 1,000 households in the islands of Santiago, São Vicente, Santo Antão, and Fogo, be made public in the Cape Verdean media." Interviewers told each respondent that "it is very important that you put the postcard in the mail if you want Cape Verdeans to be able to demand higher quality public services." 6

4. This share is likely an underestimate as it is based on official statistics, which exclude informal channels, both legal and illegal.

5. Postcards were anonymous in the sense that respondents did not have to write their names on the postcard. This is the message that interviewers were instructed to convey. However, each postcard had a six-digit number that linked each postcard to each interviewed household, so that the household and respondent characteristics were known for each returned postcard.

6. The interview, which averaged 60 minutes, asked explicit questions about the need to bribe public officials or to otherwise influence them in order to receive public services. The postcard referred to "the quality of public services" instead of "corruption" in order to minimize behavior correlated with public opinion about corruption and thus to elicit a more accurate behavioral measure of the demand for political accountability. 
The results on perceived corruption in public services would be made public if 50 percent or more of the postcards were returned. To add credibility to the survey, a "media contract" between survey fieldworkers and respondents detailed the promise that the survey results would be publicized in the national media provided at least half of respondents returned the postcards. News reports and interviews on national television, radio, and newspapers helped to publicize the media contract and to confer legitimacy on the effort.

This voting experiment was not a randomized controlled trial but rather a simple means to elicit a behavioral measure of demand for political accountability. Using a behavioral measure is likely superior to standard self-report measures, which may be tainted by "conformity bias"-respondents would be more likely to conform to what they believe are the interviewers' expectations about anticorruption attitudes. This hypothesis cannot be rejected from the empirical evidence in this article, as discussed in section IV.

\section{Theoretical Framework}

Before testing whether international emigration increases the desire for political accountability at home, a theoretical framework was developed to elucidate the determinants of voting in this postcard experiment.

There are many potentially relevant political economy theories of turnout and voting, as surveyed by Merlo (2006). Following the traditional literature on electoral participation, voter turnout was modeled as the outcome of an expected cost-benefit analysis. ${ }^{7}$

The postcard distributed to the survey respondents was prestamped, so the cost of voting was largely the opportunity cost of mailing it. This cost could depend on how familiar respondents were with posting mail and with how practical it was to do so. The cost will be higher for people who are not used to posting mail, those for whom it is more difficult to do so, and those with higher labor income.

The literature emphasizes the importance of considering an individual's calculation of expected benefits. The expected benefit of mailing the postcard arises from the desire for political accountability, which is the focus of this article. Crucially, survey respondents who are more confident about the trustworthiness and independence of the foreign institution sponsoring the survey (and about the reliability of the Cape Verdean postal system) will attribute a higher probability to the public dissemination of the results on perceived corruption. The expected benefit is finally a function of other variables directly affecting the desire for political accountability. Of greatest interest is the effect of international emigration, but factors such as gender, age, education, wealth,

7. Downs (1957) first provided a "calculus of voting" framework, which was later formalized by Tullock (1967) and Riker and Ordeshook (1968). Because of the simple nature of the voting experiment (a simple decision to vote or not), we can ignore strategic voting considerations and assume sincere voting behavior. 
and family ties must also be considered (see, for instance, Alesina and Giuliano 2009).

\section{Empirical Strategy}

An individual respondent $i$ 's voting decision on the survey (and therefore the demand for better political accountability) can be summarized by the following latent variable model:

$$
\begin{aligned}
& \left.\left.V_{i}=1\left(V_{i}^{*} \geq\right)\right]\right]> \\
V_{i}^{*}= & \alpha_{0}+\alpha_{1} M_{l}+\alpha_{2}^{\prime} X_{i}+\varepsilon_{i}
\end{aligned}
$$

This decision will be made whenever the (unobserved) expected net benefit from voting, $V_{i}^{*}$, is positive. The expected net benefit from voting depends on the local proportion of migrants, $M_{l}$, with impact $\alpha_{1}$ on voting behavior, which is the primary estimate of interest. ${ }^{8}$ The main explanatory variable is computed as:

Proportion of international migrants within the household's spatial area of residence

$$
=\frac{\text { Number of migrants in the locality }}{\text { Number of residents in the locality }}
$$

where migrants includes both current and return migrants. The effect of the local proportion of migrants on an individual's demand for good governance includes direct and indirect effects-effects arising directly from the presence of return migrants and indirect effects due to the influence return migrants exert on their peers (think, for instance, of neighbor families with no migrants who become more sensitive to governance issues after talking to a return migrant neighbor who lived in the United States for some years). An additional source of indirect migrant impact on the demand for accountability by local residents is the influence of current migrants who keep in touch with family and friends. Thus the proportion of migrants within a household's spatial area of residence can be understood as a proxy for how frequently a resident can be expected to meet migrants (or their relatives and friends) in this locality. Recall that even though the results intuitively point to the importance of return migrants, the framework is sufficiently wide to encompass the impact on the locality of origin of current migrants-through their contacts with family and friends, for instance.

Second, the empirical specification includes a vector of individual, household, and locality characteristics, $\mathbf{X}_{i}$, determining the costs and benefits of mailing the voting postcard. This vector includes individual demographics (such as age as a determinant of the ease of mailing the postcard and of the

8. Locality here is a census area in Cape Verde, which corresponds roughly to a small neighborhood, where social interaction would be expected to occur. 
demand for accountability) and individual controls for how familiar someone is with posting mail and how practical it is. In addition, there is an individual indicator of confidence in the foreign institution sponsoring the survey and experiment. At the household level, vector $\mathbf{X}_{i}$ includes variables such as family structure and asset ownership, which are likely determinants of an individual's subjective valuation of the benefit of improved governance. At the locality level, the analysis controls for average expenditure per capita and for the share of local residents working in agriculture, construction, and retail trade, which may also influence the perceived benefit of better governance. All regressions also include island fixed effects.

Probit regressions are used to estimate this empirical model. Variation of migration behavior across localities, after controlling for individual, household, and local characteristics, is the source of variation that enables identification of the main coefficient of interest, $\alpha_{1}$.

Unlike with family-level variation, using locality-level variation mitigates self-selection concerns based on unobservable characteristics: unobserved ability (which may increase both migration and demand for good governance) may be correlated across family members but that is not likely at the locality level. Indeed, using locality-level variation should permit averaging out unobserved heterogeneity to some extent, thus avoiding the most apparent endogeneity problems. Moreover, Cape Verde is a small, homogeneous country, which rules out the most obvious (potentially omitted) factors that could promote migration and accountability demand simultaneously at the locality level.

\section{Data Description: Tailored Household Survey}

The empirical work is based on a household survey on migration and the quality of public services designed to answer the research questions. The survey was conducted in Cape Verde from December 2005 to March 2006 by the authors, who were affiliated with the University of Oxford. (Additional details on the fieldwork and survey are at www.csae.ox.ac.uk/resprogs/corruption/cv/ cv.htm.)

The survey was submitted to a representative sample of 1,066 resident households (997 complete interviews) in 5 percent of the 561 census areas of Cape Verde. This sample provided information on resident nonmigrants and return migrants and on a large sample of current emigrants. The questionnaire included a module on the perceived quality/corruption of public services and one on migration characteristics of the household (including full migration histories). The interviewed household member, who had to be at least 30 years old, was asked to provide the socio-demographic characteristics of all household members, including children living elsewhere. The respondent was also asked to characterize all migration spells of household members, including who emigrated, where, and when. Finally, there were questions about the 
household's economic situation, such as living standards, income, and whether any member had received remittances the previous year. (An English translation of the questionnaire is available at www.csae.ox.ac.uk/resprogs/ corruption/cv/questcveng.pdf.)

Face to face survey interviews were conducted by teams of local interviewers and the authors, who recruited and trained the local teams. Interviewers received at least 18 hours of training in groups of two or three on understanding the content/objectives of the survey, answering the questionnaire, and piloting.

Census areas for the sample were chosen randomly, with weighting by number of households, and households within a census area were chosen randomly using standard techniques ( $n$th house, with second visits attempted the same day). To be eligible, members of the household had to be resident in the country any time during 1985-2006.

The random sampling of households had two weaknesses: differences in the number of attempts to interview a selected household in the different census areas and differences in the number of nonresponses. Weighted data were used to account for these problems, although differences from unweighted data are negligible. Data collected on nonrespondents on their gender, approximate age, approximate schooling, and approximate income were used for this purpose.

About half the respondents did not provide information on income, so regressions were run with 452 observations, at most. ${ }^{9}$

The survey data on nonmigrants, return migrants, and current migrants show that relative to nonmigrants, current emigrants are slightly more likely to be male and in their prime working years (ages 21-50; table 1). They are also more likely to have a postsecondary education. Return migrants are strongly more likely to be male (compared with both residents and current migrants) and most are over 50 years old. They tend to be less educated than current migrants, but are still more likely than residents to have a postsecondary education.

The survey results on annual migration flows over 2000-05 are close to those for the last national census period 1995-2000 (INE 2002), for both migrant outflows (around 4 percent) and returns (about 20 percent). Portugal (55 percent) and the United States (20 percent) are the main destination

9. An attrition analysis was conducted to evaluate the impact of the missing observations on the baseline econometric results (with and without controls) using multiple imputation methods. It showed that comparing the effect of local migration on voting behavior when observations without income information are excluded has a large impact on the magnitude and significance of the estimated results. When multiple imputation methods were used to recover the missing information, the magnitude of estimated coefficients falls but the statistical significance remains. This suggests that the missing income observations influence the magnitude of estimated effects, which would likely be smaller were income data available for all respondents, but that the positive sign and statistical significance of the estimates remain in all possible specifications. The results are fairly stable, however, regardless of the number of imputations performed (if anything, results improve as the number of imputations rises). 
Table 1. Characteristics of Cape Verdean Migrants and Nonmigrants

\begin{tabular}{lccc}
\hline Characteristic & Nonmigrants & Current migrants & Return migrants \\
\hline Sample size & 4997 & 907 & 241 \\
Gender (\%) & 48 & 52 & 64 \\
Male & 52 & 48 & 36 \\
Female & & & \\
Age (\%) & 21.4 & 0.4 & 2.4 \\
0-10 years & 28.6 & 11.2 & 4.9 \\
11-20 years & 12.9 & 33.9 & 5.5 \\
21-30 years & 13.1 & 25.0 & 17.6 \\
31-40 years & 10.1 & 20.5 & 15.8 \\
41-50 years & 4.4 & 8.0 & 11.5 \\
51-60 years & 4.2 & 0.9 & 18.8 \\
61-70 years & 3.8 & 0.2 & 20.6 \\
$71-80$ years & 1.2 & 0.0 & 3.0 \\
81-90 years & 0.02 & 0.0 & 0.00 \\
91 years & & & \\
Education (males ages $15-64 ; \%)$ & 3.7 & 3.6 & 5.2 \\
No education & 1.5 & 0.7 & 0.0 \\
Preschool & 11.4 & 8.2 & 14.3 \\
Basic reading and writing & 59.7 & 62.4 & 50.7 \\
Primary & 18.8 & 9.9 & 19.5 \\
Intermediate secondary & 1.1 & 0.4 & 3.9 \\
Secondary & 3.8 & & 6.5 \\
Postsecondary & & &
\end{tabular}

Note: Numbers may not sum to 100 because of rounding.

Source: Authors' survey.

countries for migrants; again, these results are similar to official census statistics (INE 2002). The next most popular destinations are European countries (France with $12 \%$, Netherlands and Luxemburg with $2 \%$ each) and Brazil (with $3 \%$ ).

Because only 43 percent of the postcards were returned, the results of the survey were not published in the national media.

\section{EMPiRICAL RESUlts}

This section on the main empirical results focuses on the robustness of the estimates of a gain in the demand for political accountability arising from international migration.

\section{Baseline Results}

The baseline estimation of the probability of a given survey respondent returning the postcard is shown in table 2 (column 1). Even before controlling for other covariates (except for urban locality and island fixed effects), there is 
Ta ble 2. Probability of Mailing Voting Postcard (Columns 1-6, Marginal Effects of Probit Estimates) and Probability of Self-reported Demand for Accountability (Column 7, Ordered Probit Estimates): Baseline Results

\begin{tabular}{|c|c|c|c|c|c|c|c|}
\hline Variable & (1) & (2) & (3) & (4) & (5) & (6) & (7) \\
\hline $\begin{array}{l}\text { Proportion of international migrants } \\
\text { (relative to residents) in locality }\end{array}$ & $\begin{array}{l}0.9419 \\
(0.3465) * * *\end{array}$ & $\begin{array}{l}0.9446 \\
(0.3512) * * *\end{array}$ & $\begin{array}{l}1.0103 \\
(0.3623) * * *\end{array}$ & $\begin{array}{l}1.0724 \\
(0.3510) * * *\end{array}$ & $\begin{array}{l}1.1034 \\
(0.3859) * * *\end{array}$ & $\begin{array}{l}1.0886 \\
(0.3677) * * *\end{array}$ & $\begin{array}{c}2.0218 \\
(1.3204)\end{array}$ \\
\hline Trust in Oxford University & & $\begin{array}{c}0.0077 \\
(0.0232)\end{array}$ & $\begin{array}{c}0.0211 \\
(0.0231)\end{array}$ & $\begin{array}{c}0.0228 \\
(0.0226)\end{array}$ & $\begin{array}{c}0.0334 \\
(0.0238)\end{array}$ & $\begin{array}{c}0.0348 \\
(0.0237)\end{array}$ & $\begin{array}{c}0.0365 \\
(0.0665)\end{array}$ \\
\hline Habit of posting & & $\begin{array}{c}0.0045 \\
(0.0132)\end{array}$ & $\begin{array}{c}0.0083 \\
(0.0127)\end{array}$ & $\begin{array}{c}0.0100 \\
(0.0127)\end{array}$ & $\begin{array}{c}0.0089 \\
(0.0137)\end{array}$ & $\begin{array}{c}0.0092 \\
(0.0138)\end{array}$ & $\begin{array}{l}-0.0152 \\
(0.0267)\end{array}$ \\
\hline Male & & & $\begin{array}{l}-0.0863 \\
(0.0485) *\end{array}$ & $\begin{array}{l}-0.0928 \\
(0.0467)^{* *}\end{array}$ & $\begin{array}{r}-0.0751 \\
(0.0485)\end{array}$ & $\begin{array}{r}-0.0751 \\
(0.0485)\end{array}$ & $\begin{array}{c}0.1954 \\
(0.1179) *\end{array}$ \\
\hline Age & & & $\begin{array}{c}0.0207 \\
(0.0134)\end{array}$ & $\begin{array}{c}0.0161 \\
(0.0143)\end{array}$ & $\begin{array}{c}0.0131 \\
(0.0143)\end{array}$ & $\begin{array}{c}0.0140 \\
(0.0142)\end{array}$ & $\begin{array}{l}-0.0602 \\
(0.0304) * *\end{array}$ \\
\hline Age squared & & & $\begin{array}{c}-0.0002 \\
(0.0001)\end{array}$ & $\begin{array}{c}-0.0002 \\
(0.0001)\end{array}$ & $\begin{array}{c}-0.0001 \\
(0.0001)\end{array}$ & $\begin{array}{c}-0.0001 \\
(0.0001)\end{array}$ & $\begin{array}{c}0.0004 \\
(0.0003)\end{array}$ \\
\hline Individual labor income & & & $\begin{array}{l}-0.0002 \\
(0.0001) * *\end{array}$ & $\begin{array}{l}-0.0002 \\
(0.0001) * *\end{array}$ & $\begin{array}{l}-0.0003 \\
(0.0001) * *\end{array}$ & $\begin{array}{l}-0.0003 \\
(0.0001) * *\end{array}$ & $\begin{array}{c}0.0001 \\
(0.0003)\end{array}$ \\
\hline Number of children & & & & $\begin{array}{l}0.0205 \\
(0.0120)^{*}\end{array}$ & $\begin{array}{l}0.0212 \\
(0.0120)^{*}\end{array}$ & $\begin{array}{l}0.0215 \\
(0.0121)^{*}\end{array}$ & $\begin{array}{c}0.0189 \\
(0.0296)\end{array}$ \\
\hline
\end{tabular}

(Continued) 
TABLE 2. Continued

\begin{tabular}{|c|c|c|c|c|c|c|c|}
\hline Variable & (1) & (2) & (3) & (4) & (5) & (6) & (7) \\
\hline $\begin{array}{l}\text { Average private consumption expenditure } \\
\text { per capita in locality }\end{array}$ & & & & & $\begin{array}{c}0.9789 \\
(0.6637)\end{array}$ & $\begin{array}{c}0.6916 \\
(0.7866)\end{array}$ & $\begin{array}{c}-0.9512 \\
(1.8530)\end{array}$ \\
\hline $\begin{array}{l}\text { Share of residents working in agriculture in } \\
\text { locality }\end{array}$ & & & & & $\begin{array}{c}-0.8688 \\
(0.5572)\end{array}$ & $\begin{array}{l}-1.2906 \\
(0.9234)\end{array}$ & $\begin{array}{c}-0.1134 \\
(2.1112)\end{array}$ \\
\hline $\begin{array}{l}\text { Share of residents working in construction } \\
\text { in locality }\end{array}$ & & & & & $\begin{array}{l}-0.5909 \\
(1.1277)\end{array}$ & $\begin{array}{l}-0.7994 \\
(1.1626)\end{array}$ & $\begin{array}{l}-6.8096 \\
(2.5307)^{* * *}\end{array}$ \\
\hline $\begin{array}{l}\text { Share of residents working in retail trade } \\
\text { in locality }\end{array}$ & & & & & $\begin{array}{c}1.2200 \\
(1.6264)\end{array}$ & $\begin{array}{c}0.9100 \\
(1.7060)\end{array}$ & $\begin{array}{c}4.2588 \\
(3.3857)\end{array}$ \\
\hline $\begin{array}{l}\text { Share of households receiving international } \\
\text { remittances in locality }\end{array}$ & & & & & & $\begin{array}{c}0.9963 \\
(1.3944)\end{array}$ & \\
\hline Number of observations & 452 & 452 & 452 & 452 & 452 & 452 & 451 \\
\hline
\end{tabular}

* Significant at the 10 percent level; ** significant at the 5 percent level; ** significant at the 1 percent level.

Note: Numbers in parentheses are robust standard errors clustered at the locality level. All regressions include urban locality dummy variable and island fixed effects. Self-reported demand for accountability is expressed as a 1-7 scale.

Source: Authors' analysis based on authors' survey. 
a striking statistically significant difference between the postcard voting probability of localities depending on the ratio of migrants to residents (each percentage point increase in the ratio of migrants to residents, including both current and return migrants, leads to a 0.94 percentage point increase in the probability of voting). After controlling for several individual- and household-level covariates, the observed voting differences remain (see table 2, columns 2-4).

The signs of all significant coefficients are as expected and do not vary as additional controls are included. Because of the potential for omitted-variable bias, several locality-level controls are added, such as average private consumption expenditure per capita and the occupational structure in the locality. The addition of these controls does not alter the magnitude and significance of the estimated effect (table 2, column 5). Another concern is that international migration may be proxying for important local financial characteristics, so that international remittances may also matter as determinants of the desire for better governance. That does not seem to be the case: including the proportion of local households receiving international remittances has an insignificant economic and statistical impact and almost no affect on the estimated coefficients and significances of the other determinants included in the regression (table 2, column 6).

The baseline estimates are therefore those presented in column 5 of table 2 . There is a strong negative income/wealth effect on the demand for more accountability. Having annual labor income with a negative estimated coefficient would be difficult to interpret directly as a negative income effect as this could simply be proxying the opportunity cost (time value) of mailing the postcard. However, this effect is also strong for asset ownership: wealthier people seem to place less value on the benefits of political accountability, which is consistent with Minier's (2001) finding that democracy is not a normal good. At the local level, though, the results consistently point to average expenditure per capita as positively influencing postcard mailing behavior.

\section{Baseline Robustness Checks}

Several robustness checks were conducted. Drawing from the evidence on "brain gain" (Batista, Lacuesta, and Vicente, forthcoming), the first robustness check addresses whether local education affects the way international migration for a locality generates a desire for political accountability. When controlling for local educational attainment, intermediate secondary and secondary schooling do not change the sign, magnitude, and statistical significance of the impact of local migration on the demand for political accountability (table 3, columns 1-3). A postsecondary education, however, increases the migration effects, even though the positive coefficient on postsecondary education is not significant at conventional levels.

A potential concern with these estimated effects is that the probability of mailing a postcard may depend on respondents' experience with and 
Ta ble 3. Probability of Mailing Postcard (Marginal Effects of Probit Regressions): Robustness Checks

\begin{tabular}{|c|c|c|c|c|c|c|c|c|c|c|}
\hline Variable & (1) & (2) & (3) & (4) & (5) & (6) & (7) & (8) & (9) & (10) \\
\hline $\begin{array}{l}\text { Proportion of international } \\
\text { migrants (relative to } \\
\text { residents) in locality }\end{array}$ & $\begin{array}{l}1.1091 \\
(0.3863)^{* * * *}\end{array}$ & $\begin{array}{l}1.0818 \\
(0.4054)^{* * * *}\end{array}$ & $\begin{array}{l}1.3132 \\
(0.3708)^{* * * *}\end{array}$ & $\begin{array}{l}0.9140 \\
(0.4334)^{* * *}\end{array}$ & $\begin{array}{l}1.1349 \\
(0.4159)^{* * * *}\end{array}$ & $\begin{array}{l}0.9889 \\
(0.4066)^{* * *}\end{array}$ & $\begin{array}{l}1.0639 \\
(0.3813)^{* * * *}\end{array}$ & $\begin{array}{l}0.9920 \\
(0.3680)^{* * * *}\end{array}$ & $\begin{array}{l}0.9012 \\
(0.3780)^{* * *}\end{array}$ & $\begin{array}{l}1.0104 \\
(0.4157)^{* * *}\end{array}$ \\
\hline $\begin{array}{l}\text { Ratio of residents } \\
\text { completing } \\
\text { relative to residents } \\
\text { not completing } 9 \text { years of } \\
\text { schooling in locality }\end{array}$ & $\begin{array}{l}-0.0471 \\
(0.2704)\end{array}$ & & & & & & & & & $\begin{array}{l}0.5362 \\
(0.3314)\end{array}$ \\
\hline $\begin{array}{l}\text { Ratio of residents } \\
\text { completing } \\
\text { relative to residents } \\
\text { not completing } 12 \text { years } \\
\text { of } \\
\text { schooling in locality }\end{array}$ & & $\begin{array}{l}-0.3184 \\
(0.4014)\end{array}$ & & & & & & & & $\begin{array}{l}-2.0897 \\
(0.7537)^{* * * *}\end{array}$ \\
\hline $\begin{array}{l}\text { Ratio of residents } \\
\text { completing } \\
\text { relative to residents } \\
\text { not completing } 15 \text { years } \\
\text { of } \\
\text { schooling in locality }\end{array}$ & & & $\begin{array}{l}1.8460 \\
(1.1037)^{*}\end{array}$ & & & & & & & $\begin{array}{l}6.1358 \\
(1.9907)^{* * * *}\end{array}$ \\
\hline $\begin{array}{l}\text { Perceived corruption in } \\
\text { health sector }\end{array}$ & & & & 0.0381 & & & & & & 0.0150 \\
\hline & & & & $(0.0147)^{* * * *}$ & & & & & & $(0.0182)$ \\
\hline $\begin{array}{l}\text { Perceived corruption in } \\
\text { education sector }\end{array}$ & & & & & $\begin{array}{l}0.0382 \\
(0.0154)^{* * *}\end{array}$ & & & & & $\begin{array}{l}0.0364 \\
(0.0191 *\end{array}$ \\
\hline
\end{tabular}


Wait to mail until passes a postbox

Gives to (taxi) driver to post

\begin{tabular}{|c|c|c|c|}
\hline \multicolumn{3}{|l|}{$(0.1955)$} & $(0.2044)$ \\
\hline \multicolumn{3}{|l|}{0.1933} & 0.0552 \\
\hline \multicolumn{3}{|l|}{$(0.1696)$} & $(0.2303)$ \\
\hline \multicolumn{3}{|l|}{0.0884} & -0.0237 \\
\hline \multicolumn{3}{|l|}{$(0.1390)$} & $(0.1515)$ \\
\hline \multicolumn{4}{|l|}{0.3767} \\
\hline \multicolumn{4}{|l|}{$(0.2607)$} \\
\hline \multicolumn{3}{|l|}{0.0945} & 0.0180 \\
\hline \multirow[t]{5}{*}{$(0.1167)$} & & & $(0.1287)$ \\
\hline & -0.0078 & & -0.0128 \\
\hline & $(0.0149)$ & & $(0.0219)$ \\
\hline & & 0.0119 & 0.0358 \\
\hline & & $(0.0130)$ & $(0.0251)$ \\
\hline 451 & 443 & 445 & 363 \\
\hline
\end{tabular}

Gives to family member to

post

Gives to letter carrier

Makes intentional trip to postbox

Time to postbox

Comfort in posting mail

Number of observations

* Significant at the 10 percent level; ** significant at the 5 percent level; $* *$ significant at the 1 percent level.

Note: Numbers in parentheses are robust standard errors clustered at the locality level. All regressions include the same controls as the baseline regression in column 5 of table 2 .

Source: Authors' analysis based on authors' survey. 
perceptions of corruption. That is indeed the case: respondents who perceive more corruption in the health and education sectors (the sectors most respondents had contact with) are significantly more likely to mail the postcard (table 3, columns 4-5). The impact of perceived corruption also affects the magnitude and significance of the impact of international emigration, but the impact is not systematically in one direction. Overall, the sign, magnitude, and broad statistical significance of the effect of international migration remain stable throughout the different specifications. This result points to an intuitive, crucial role of perceived corruption in creating incentives for greater demand for accountability.

Another important issue is to control properly for the cost of mailing the postcard and the confidence when doing so. The sign, magnitude, and significance of the estimated coefficients on local international emigration are not strongly affected by the choice of these controls (table 3, columns 6-9). None of these controls is ever statistically significant. This is consistent with the idea that, although incentive compatible, the costs of mailing the postcard are of slight importance to the results.

When all the alternative controls are used simultaneously in a single regression, the main coefficient of interest has the same magnitude as that estimated using other important controls and is again significant at the 5 percent level despite the loss of observations implied by using all controls simultaneously (table 3, column 10).

\section{Mechanics 1: Migrant Destination}

Having established the relevance of local migration in determining voting behavior in the experimental setting, it is reasonable to wonder about the mechanisms underlying this result. How does local migration affect behavior? One approach is to examine how the destination of local migrants affects the results. A comparison of the effect of the two main migrant destinations, Portugal and the United States, is striking: only migration to the United States has a sizable and significant impact on the desire for better governance (table 4, columns 1 and 2). The effects of local migration to Portugal are not statistically significant.

\section{Mechanics 2: Current and Return Migrants}

Continuing along this line of investigation, it is possible to distinguish between the effects of current and return migrants by country of destination (table 5, columns 1 and 2). The magnitude and significance of effects are much higher for return migrants than for current migrants, regardless of country of destination. This is an intuitive result, as migrants' experience is more likely to affect the community of residence once migrants return and interact with residents than while they are away. Note also that the effects of both return and current migrants to the United States are positive (although insignificant for current migrants), whereas the effect of migrants returning from Portugal is negative. 
Ta ble 4. Probability of Mailing Voting Postcard (Columns 1-7, Marginal Effects of Probit Estimates) and Probability of Self-reported Demand for Accountability (Columns 8 and 9, Ordered Probit Estimates)

\begin{tabular}{|c|c|c|c|c|c|c|c|c|c|}
\hline Variable & (1) & (2) & (3) & (4) & (5) & (6) & (7) & (8) & (9) \\
\hline $\begin{array}{l}\text { Proportion of } \\
\text { international } \\
\text { migrants to } \\
\text { Portugal (relative } \\
\text { to residents) in } \\
\text { locality }\end{array}$ & $\begin{array}{c}1.1210 \\
(1.0271)\end{array}$ & $\begin{array}{c}0.5435 \\
(1.1214)\end{array}$ & $\begin{array}{c}0.6185 \\
(1.3669)\end{array}$ & $\begin{array}{c}0.7998 \\
(1.1458)\end{array}$ & $\begin{array}{c}0.6865 \\
(1.0633)\end{array}$ & $\begin{array}{c}0.1818 \\
(1.2426)\end{array}$ & $\begin{array}{c}0.2358 \\
(1.2329)\end{array}$ & $\begin{array}{c}-3.0466 \\
(2.3588)\end{array}$ & $\begin{array}{c}-0.3748 \\
(2.4081)\end{array}$ \\
\hline $\begin{array}{l}\text { Proportion of } \\
\text { international } \\
\text { migrants to } \\
\text { United States } \\
\text { (relative to } \\
\text { residents) in } \\
\text { locality }\end{array}$ & $\begin{array}{l}2.7384 \\
(0.8777) * * *\end{array}$ & $\begin{array}{l}2.6239 \\
(1.0761)^{* *}\end{array}$ & $\begin{array}{l}2.6069 \\
(1.0271) * *\end{array}$ & $\begin{array}{l}2.5595 \\
(1.1184)^{* *}\end{array}$ & $\begin{array}{l}2.6833 \\
(0.9900) * * *\end{array}$ & $\begin{array}{l}2.3141 \\
(1.1519)^{* * *}\end{array}$ & $\begin{array}{l}3.1322 \\
(1.1275) * * *\end{array}$ & $\begin{array}{l}11.0254 \\
(2.1924) * * *\end{array}$ & $\begin{array}{l}12.6180 \\
(1.6359) * * *\end{array}$ \\
\hline $\begin{array}{l}\text { Ratio of residents } \\
\text { completing } \\
\text { relative to } \\
\text { residents not } \\
\text { completing } \\
9 \text { years of } \\
\text { schooling in } \\
\text { locality }\end{array}$ & & & $\begin{array}{c}-0.0343 \\
(0.3374)\end{array}$ & & & & & & \\
\hline $\begin{array}{l}\text { Ratio of residents } \\
\text { completing } \\
\text { relative to } \\
\text { residents not } \\
\text { completing } \\
12 \text { years of } \\
\text { schooling in } \\
\text { locality }\end{array}$ & & & & $\begin{array}{c}-0.3994 \\
(0.3812)\end{array}$ & & & & & \\
\hline
\end{tabular}


TABle 4. Continued

\begin{tabular}{|c|c|c|c|c|c|c|c|c|c|}
\hline Variable & $(1)$ & $(2)$ & (3) & (4) & (5) & (6) & (7) & $(8)$ & (9) \\
\hline $\begin{array}{l}\text { Ratio of residents } \\
\text { completing } \\
\text { relative to } \\
\text { residents not } \\
\text { completing } \\
15 \text { years of } \\
\text { schooling in } \\
\text { locality }\end{array}$ & & & & & $\begin{array}{c}1.1284 \\
(1.0349)\end{array}$ & & & & \\
\hline $\begin{array}{l}\text { Perceived } \\
\text { corruption in } \\
\text { health sector }\end{array}$ & & & & & & $\begin{array}{l}0.0372 \\
(0.0148)^{* *}\end{array}$ & & & \\
\hline $\begin{array}{l}\text { Perceived } \\
\text { corruption in } \\
\text { education sector }\end{array}$ & & & & & & & $\begin{array}{l}0.0390 \\
(0.0157)^{* * *}\end{array}$ & & \\
\hline Controls included & No & Yes & Yes & Yes & Yes & Yes & Yes & No & Yes \\
\hline $\begin{array}{l}\text { Number of } \\
\text { observations }\end{array}$ & 452 & 452 & 452 & 452 & 452 & 426 & 400 & 451 & 451 \\
\hline
\end{tabular}

"Significant at the 10 percent level; ** significant at the 5 percent level; *** significant at the 1percent level.

Note: Numbers in parentheses are robust standard errors clustered at the locality level. All regressions include the same controls as the baseline regression in column 5 of table 2. Self-reported demand for accountability is expressed as a 1-7 scale.

Source: Authors' analysis based on authors' survey. 
Taвle 5. Probability of Mailing Voting Postcard (Columns 1-7, Marginal Effects of Probit Estimates) and Probability of Self-reported Demand for Accountability (Columns 8 and 9, Ordered Probit Estimates)

\begin{tabular}{|c|c|c|c|c|c|c|c|c|c|}
\hline Variable & (1) & (2) & (3) & (4) & $(5)$ & (6) & $(7)$ & (8) & (9) \\
\hline $\begin{array}{l}\text { Proportion of current } \\
\text { international } \\
\text { migrants to } \\
\text { Portugal (relative } \\
\text { to residents) in } \\
\text { locality }\end{array}$ & $\begin{array}{c}2.0057 \\
(1.1713)^{*}\end{array}$ & $\begin{array}{c}0.9979 \\
(1.3858)\end{array}$ & $\begin{array}{c}0.8934 \\
(1.4444)\end{array}$ & $\begin{array}{c}0.9949 \\
(1.3717)\end{array}$ & $\begin{array}{c}1.8130 \\
(1.4379)\end{array}$ & $\begin{array}{c}0.7794 \\
(1.5497)\end{array}$ & $\begin{array}{c}0.9772 \\
(1.5515)\end{array}$ & $\begin{array}{c}-4.2651 \\
(3.2703)\end{array}$ & $\begin{array}{c}-2.0208 \\
(2.9193)\end{array}$ \\
\hline $\begin{array}{l}\text { Proportion of current } \\
\text { international } \\
\text { migrants to United } \\
\text { States (relative to } \\
\text { residents) in } \\
\text { locality }\end{array}$ & $\begin{array}{c}0.9286 \\
(2.1526)\end{array}$ & $\begin{array}{c}0.0938 \\
(3.0738)\end{array}$ & $\begin{array}{c}0.4789 \\
(3.0037)\end{array}$ & $\begin{array}{c}0.0001 \\
(3.1214)\end{array}$ & $\begin{array}{c}0.8021 \\
(2.8120)\end{array}$ & $\begin{array}{c}-1.2650 \\
(3.8085)\end{array}$ & $\begin{array}{c}0.9654 \\
(3.3864)\end{array}$ & $\begin{array}{c}4.5386 \\
(7.2504)\end{array}$ & $\begin{array}{c}6.9932 \\
(7.0402)\end{array}$ \\
\hline $\begin{array}{l}\text { Proportion of } \\
\text { international return } \\
\text { migrants to } \\
\text { Portugal (relative } \\
\text { to residents) in } \\
\text { locality }\end{array}$ & $\begin{array}{l}-4.8152 \\
(2.4159) * *\end{array}$ & $\begin{array}{l}-4.9271 \\
(2.8707) *\end{array}$ & $\begin{array}{l}-6.0974 \\
(3.6964) *\end{array}$ & $\begin{array}{c}-4.0434 \\
(3.3599)\end{array}$ & $\begin{array}{l}-6.6494 \\
(2.4733) * * *\end{array}$ & $\begin{array}{l}-7.0375 \\
(3.5251) * *\end{array}$ & $\begin{array}{l}-5.8158 \\
(3.4314) *\end{array}$ & $\begin{array}{l}-4.4922 \\
(12.3565)\end{array}$ & $\begin{array}{c}0.9119 \\
(12.8589)\end{array}$ \\
\hline $\begin{array}{l}\text { Proportion of } \\
\text { international return } \\
\text { migrants to United } \\
\text { States (relative to } \\
\text { residents) in } \\
\text { locality }\end{array}$ & $\begin{array}{l}4.5445 \\
(2.5979) *\end{array}$ & $\begin{array}{l}5.0953 \\
(2.3956) * *\end{array}$ & $\begin{array}{l}4.7343 \\
(2.4130)^{* *}\end{array}$ & $\begin{array}{l}5.1888 \\
(2.4798) * *\end{array}$ & $\begin{array}{l}4.2942 \\
(2.3635)^{*}\end{array}$ & $\begin{array}{l}5.7620 \\
(2.7759) * *\end{array}$ & $\begin{array}{l}5.0397 \\
(2.5711) * *\end{array}$ & $\begin{array}{l}19.7322 \\
(6.9132) * * *\end{array}$ & $\begin{array}{l}19.8166 \\
(7.1887) * * *\end{array}$ \\
\hline $\begin{array}{l}\text { Ratio of residents } \\
\text { completing relative } \\
\text { to residents not } \\
\text { completing } 9 \text { years } \\
\text { of schooling in } \\
\text { locality }\end{array}$ & & & $\begin{array}{c}0.1610 \\
(0.3662)\end{array}$ & & & & & & \\
\hline
\end{tabular}


TABLE 5. Continued

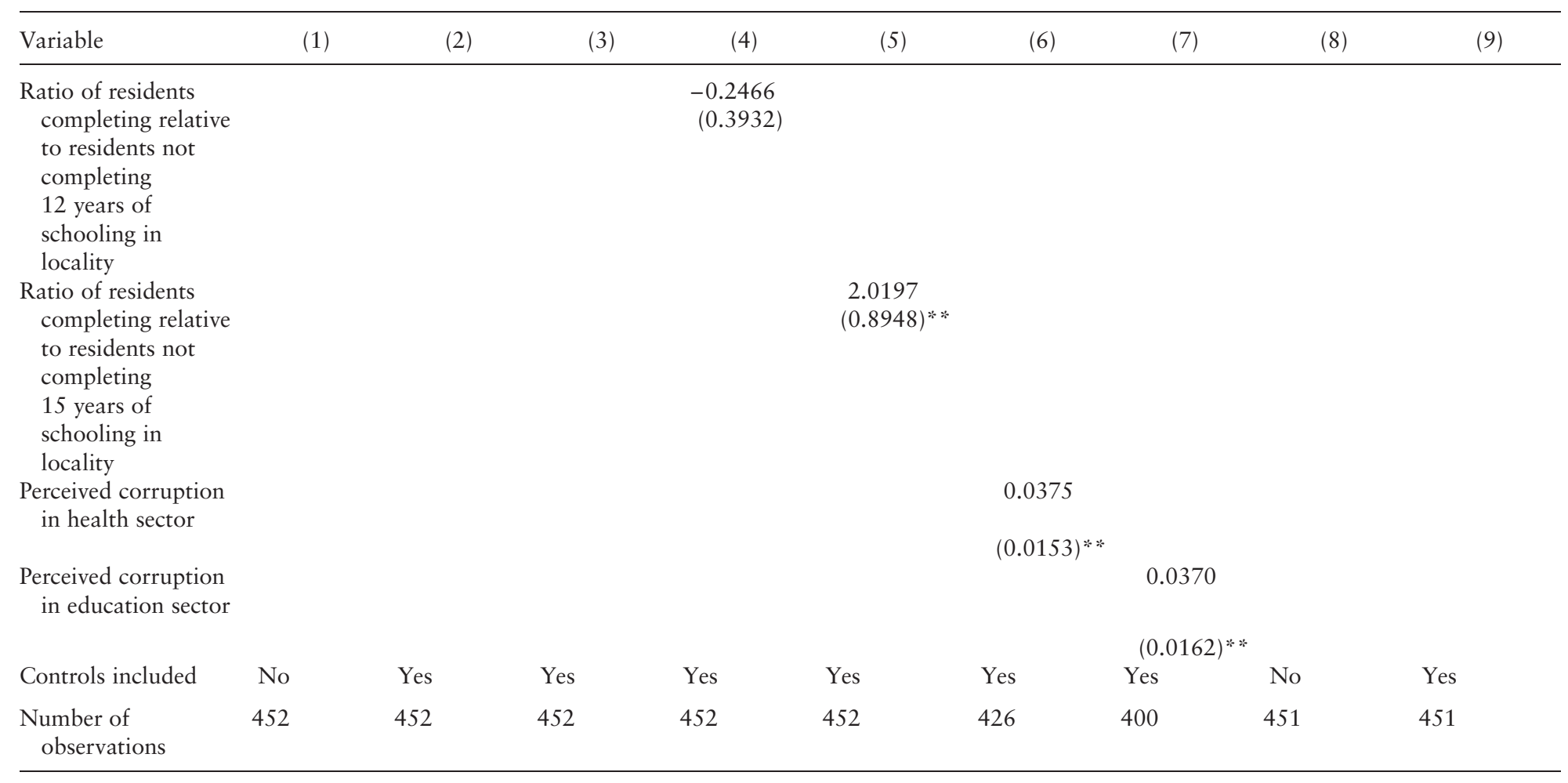

"Significant at the 10 percent level; ** significant at the 5percent level; *** significant at the 1 percent level.

Note: Numbers in parentheses are robust standard errors clustered at the locality level. All regressions include the same controls as the baseline regression in column 5 of table 2 . Self-reported demand for accountability is expressed as a $1-7$ scale.

Source: Authors' analysis based on authors' survey. 


\section{Robustness Checks: Self-selection}

How can we ensure that the estimated local migration effects are really causing the demand for accountability? One might conjecture that selection (for instance, on observable characteristics such as education) is driving the findings. To examine this possibility, the differences in means were estimated between localities with strong migration to Portugal (migrants to Portugal constitute at least 5 percent of the resident population) and those without; the same was done for migration to the United States.

Households in areas prone to migration to Portugal are usually less well off than those in areas prone to migration to the United States, although those prone to migrate to the United States seem to possess above mean assets that could allow them to overcome the financial costs of an international move (table 6). Migrants to Portugal tend to originate in areas where agriculture and construction dominate over services, such as retail trade; the reverse is true for migrants to the United States. Education profiles differ as well: the most educated migrants move to the United States, an expected outcome considering the higher costs involved (financial, language, and distance). Finally, there is a slightly higher perception of corruption in the health sector in areas with strong migration to Portugal.

With such a profile, it is desirable to control for local educational attainment in regressions evaluating the impact of migration by destination country. The effects of education are not visible at the aggregate level, when the impact of all migrants to different destinations is considered (see table 4, column 3-5). Only when the analysis is decomposed into current and return migrants does the impact become apparent. The most striking dimension of selectivity in migration, college education, also has the greatest impact on the results. After controlling for tertiary education, the impact of return migration from Portugal becomes significantly negative (see table 5, columns 3-5) - this may be related to the fact that Cape Verde had no universities until 1995 and that Portugal was the usual destination for Cape Verdeans seeking a college education. Apart from this strong impact on the coefficient on return migration from Portugal, the estimated results are not very sensitive to this or other dimensions along which migrants seem to self-select when choosing a migration destination.

This result indicates that self-selection is not likely to underlie the impact of migration on the demand for political accountability. Indeed, migrant assimilation of the accountability norms in the destination country is a better explanation for this impact. ${ }^{10}$ In the latest Transparency International (2009)

10. This is consistent with the findings of Fidrmuc and Doyle (2004) and Spilimbergo (2009), which also provide evidence supporting migrant assimilation effects in the destination country. Fidrmuc and Doyle (2004) focus on Czech and Polish migrants and also find that self-selection (by political attitudes and economic characteristics) is not likely to explain migrants' political attitudes. Spilimbergo (2009) describes how the political attitudes of migrants differ depending on the political characteristics of the destination countries. 
Table 6: Descriptive Statistics for Survey Respondents in Areas with Strong Migration to Portugal and Areas with Strong Migration to the United States

\begin{tabular}{|c|c|c|}
\hline Variable & $\begin{array}{l}\text { Strong migration to } \\
\text { Portugal }\end{array}$ & $\begin{array}{l}\text { Strong migration to } \\
\text { United States }\end{array}$ \\
\hline Male & $\begin{array}{c}-0.0001 \\
(0.0500)\end{array}$ & $\begin{array}{c}0.0726 \\
(0.0732)\end{array}$ \\
\hline Age & $\begin{array}{l}1.18987 \\
(1.4803)\end{array}$ & $\begin{array}{c}0.8926 \\
(2.0500)\end{array}$ \\
\hline Individual labor income & $\begin{array}{l}-82.8924 \\
(26.9850) * * *\end{array}$ & $\begin{array}{c}19.6443 \\
(41.7703)\end{array}$ \\
\hline Number of children & $\begin{array}{c}0.1787 \\
(0.2490)\end{array}$ & $\begin{array}{r}-0.3183 \\
(0.2903)\end{array}$ \\
\hline Household asset ownership & $\begin{array}{l}0.1252 \\
(0.0317) * * *\end{array}$ & $\begin{array}{r}-0.0280 \\
(0.0564)\end{array}$ \\
\hline Trust in Oxford University & $\begin{array}{l}0.2551 \\
(0.1089) * *\end{array}$ & $\begin{array}{r}-0.1278 \\
(0.1679)\end{array}$ \\
\hline Habit of posting & $\begin{array}{l}-0.3219 \\
(0.1967)\end{array}$ & $\begin{array}{l}-0.2356 \\
(0.2681)\end{array}$ \\
\hline $\begin{array}{l}\text { Average private consumption expenditure per } \\
\text { capita in locality }\end{array}$ & $\begin{array}{c}0.0077 \\
(0.0058)\end{array}$ & $\begin{array}{l}0.0316 \\
(0.0112) * * *\end{array}$ \\
\hline $\begin{array}{l}\text { Fraction of residents working in agriculture in } \\
\text { locality }\end{array}$ & $\begin{array}{l}0.0322 \\
(0.0043) * * *\end{array}$ & $\begin{array}{c}0.0017 \\
(0.0047)\end{array}$ \\
\hline $\begin{array}{l}\text { Fraction of residents working in construction in } \\
\text { locality }\end{array}$ & $\begin{array}{l}0.0227 \\
(0.0029) * * *\end{array}$ & $\begin{array}{l}-0.0181 \\
(0.0026) * * *\end{array}$ \\
\hline $\begin{array}{l}\text { Fraction of residents working in retail trade in } \\
\text { locality }\end{array}$ & $\begin{array}{l}-0.0057 \\
(0.0024) * *\end{array}$ & $\begin{array}{l}-0.0119 \\
(0.0021) * * *\end{array}$ \\
\hline $\begin{array}{l}\text { Fraction of households receiving international } \\
\text { remittances in locality }\end{array}$ & $\begin{array}{c}0.0028 \\
(0.0020)\end{array}$ & $\begin{array}{l}0.0279 \\
(0.0044) * * *\end{array}$ \\
\hline $\begin{array}{l}\text { Ratio of residents completing relative to residents } \\
\text { not completing } 9 \text { years of schooling in locality }\end{array}$ & $\begin{array}{r}-0.0239 \\
(0.0229)\end{array}$ & $\begin{array}{l}0.0886 \\
(0.0479) *\end{array}$ \\
\hline $\begin{array}{l}\text { Ratio of residents completing relative to residents } \\
\text { not completing } 12 \text { years of schooling in locality }\end{array}$ & $\begin{array}{l}-0.0265 \\
(0.0110) *\end{array}$ & $\begin{array}{l}0.0448 \\
(0.0200) * *\end{array}$ \\
\hline $\begin{array}{l}\text { Ratio of residents completing relative to residents } \\
\text { not completing } 15 \text { years of schooling in locality }\end{array}$ & $\begin{array}{l}-0.0097 \\
(0.0031) * * *\end{array}$ & $\begin{array}{l}0.0172 \\
(0.0058) * * *\end{array}$ \\
\hline Perceived corruption in health sector & $\begin{array}{l}0.4074 \\
(0.2149)^{*}\end{array}$ & $\begin{array}{l}-0.1839 \\
(0.2659)\end{array}$ \\
\hline Perceived corruption in education sector & $\begin{array}{r}-0.0358 \\
(0.1845)\end{array}$ & $\begin{array}{r}-0.3119 \\
(0.2377)\end{array}$ \\
\hline
\end{tabular}

* Significant at the 10 percent level; * significant at the 5 percent level; $* *$ significant at the 1 percent level.

Note: Numbers in parentheses are robust standard errors clustered at the locality level. Strong migration to a certain destination is defined as migrants to that destination representing at least 5 percent of the resident population. Table shows mean difference relative to areas where migration to the same destination is not strong.

Source: Authors' analysis based on authors' survey.

cross-country governance ranking, the United States places $19^{\text {th }}$, Portugal ranks $35^{\text {th }}$ and Cape Verde $46^{\text {th }}$. This evidence can be interpreted to show that the experience of emigrants to the United States is more conducive to promoting demand for better governance than that of emigrants to Portugal. Also, the 
negative impact of return migrants from Portugal should be viewed in the context of the baseline destinations against which migrants to the United States and Portugal are being compared; those are mostly European countries, such as France and the Netherlands, which rank closer to the United States in governance than to Portugal or Cape Verde.

\section{Robustness Check: Potential Endogeneity and Instrumental Variable Estimation}

Despite the supportive evidence that observable self-selection does not seem to explain the estimated results, there may still be endogeneity concerns related to potential unobserved heterogeneity and locality-level omitted variables. To examine these concerns, the baseline regressions are reestimated using two sets of instrumental variables: five-year lagged local migrant stocks based on the full migration history available for all household members in the survey, and external sources in destination countries (unemployment rates, nominal GDP per capita, and GDP growth rates in the United States and Portugal) in the 10 years before the survey.

These variables are aggregated using a weighted sum in which the weight is the five-year lagged local migrant stock to each destination relative to the fiveyear lagged overall stock of migrants to that destination in each 10-year period. This weight can be understood as a five-year lagged proxy for migration networks in the destination country, which combined with macro information from the destination country, should constitute an exogenous source of variation for migration, enabling identification of the coefficients of interest. Note that the weighting procedure guarantees enough variation to identify the effects of interest at the locality level. The second set of instruments also enables testing for overidentification in all three estimated specifications. This second set of instruments is also stronger-lagged instrument strength could be a problem for certain regressions, as displayed in table 7 , column 7 .

After finding that the instruments used seem strong and exogenous in all possible specifications (see table 7), it is also reassuring to observe that the estimates are not substantially different from those obtained using probit methods. This finding points to the small importance of any endogeneity concerns at the local level, after controlling for all relevant covariates.

\section{Robustness Check: Alternative Measures of the Demand for Accountability}

One additional potential concern with the analysis is that the postcard experiment might not be exactly measuring a desire for political accountability. To strengthen the contention that that is the case, a survey variable is used that asks respondent directly whether they agree or disagree (on a 1-7 scale) with the statement: "As a common citizen of Cape Verde, I believe I should require competence in the public services (health centers, schools, courts, police) that are aimed at my needs." 
Table 7. Probability of Mailing Voting Postcard (Columns 1, 2, 4, 5, 7, and 8) and Probability of Self-reported Demand for Accountability (Columns 3, 6, and 9): Instrumental Variable Estimates

\begin{tabular}{|c|c|c|c|c|c|c|c|c|c|}
\hline Variable & (1) & (2) & (3) & (4) & (5) & (6) & (7) & (8) & (9) \\
\hline $\begin{array}{l}\text { Proportion of international } \\
\text { migrants (relative to } \\
\text { residents) in locality }\end{array}$ & $\begin{array}{l}1.0298 \\
(0.3895) * * *\end{array}$ & $\begin{array}{l}1.4380 \\
(0.3472) * * *\end{array}$ & $\begin{array}{l}1.8467 \\
(1.0169) *\end{array}$ & & & & & & \\
\hline $\begin{array}{l}\text { Proportion of international } \\
\text { migrants to Portugal (relative } \\
\text { to residents) in locality }\end{array}$ & & & & $\begin{array}{l}-1.0262 \\
(1.8587)\end{array}$ & $\begin{array}{l}-0.4735 \\
(1.5247)\end{array}$ & $\begin{array}{l}-0.3474 \\
(2.8333)\end{array}$ & & & \\
\hline $\begin{array}{l}\text { Proportion of international } \\
\text { migrants to United States } \\
\text { (relative to residents) in } \\
\text { locality }\end{array}$ & & & & $\begin{array}{l}2.7575 \\
(0.9659) * * *\end{array}$ & $\begin{array}{l}3.3261 \\
(0.9731) * * *\end{array}$ & $\begin{array}{l}7.7153 \\
(1.5838) * * *\end{array}$ & & & \\
\hline $\begin{array}{l}\text { Proportion of current } \\
\text { international migrants to } \\
\text { Portugal (relative to residents) } \\
\text { in locality }\end{array}$ & & & & & & & $\begin{array}{l}1.2976 \\
(9.0557)\end{array}$ & $\begin{array}{l}1.6291 \\
(1.4478)\end{array}$ & $\begin{array}{l}0.7949 \\
(2.4863)\end{array}$ \\
\hline $\begin{array}{l}\text { Proportion of current } \\
\text { international migrants to } \\
\text { United States (relative to } \\
\text { residents) in locality }\end{array}$ & & & & & & & $\begin{array}{l}3.3171 \\
(5.6915)\end{array}$ & $\begin{array}{l}-0.6921 \\
(5.8877)\end{array}$ & $\begin{array}{l}4.4871 \\
(6.7337)\end{array}$ \\
\hline
\end{tabular}


Proportion of international return migrants to Portugal

(relative to residents) in

locality

Proportion of international

return migrants to United

States (relative to residents) in

locality

Instrument set ${ }^{\mathrm{a}}$

F-statistics on excluded

instruments in first stage

regressions

Overidentification test ( $p$-value)

Controls included

Number of observations

$\begin{array}{ll}\text { A } & \text { B } \\ 394.1 & 28.1\end{array}$

B

B

28.2

$$
\text { A }
$$

A $9.5 ; 124.2 \quad$ B

列

$\begin{array}{ll}\text { NA } & 0.18 \\ \text { Yes } & \text { Yes } \\ 452 & 452\end{array}$

\section{$-2.7566$}

(11.2768)

$-4.8785$

(3.6941)

$-0.8931$

* Significant at the 10 percent level; ** significant at the 5percent level; *** significant at the 1 percent level.

Note: Numbers in parentheses are robust standard errors clustered at the locality level. All regressions include the same controls as the baseline regression in column 5 of table 2.

a. Instrument set A includes five-year lagged regressors of interest. Instrument set B uses macroeconomic variables at destination weighted by five-year lagged local migration stock size indicators, as described in the text.
$(3.6264) \quad(3.2493) \quad(4.8695) * *$

B $\quad$ B

$3.9 ; 11.5 ; 13.9 ; 11.6$

180.7; 178.2 ;

$\begin{array}{ccc}378.1 & 1156.5 & 1169.1 \\ \text { NA } & 0.15 & 0.38\end{array}$

Yes Yes $\quad$ Yes

$452 \quad 452 \quad 451$

es 
This self-reported measure of demand for better governance is used to verify whether the determinants of postcard voting behavior are similar. The results are reassuring. The sign and significance of the main estimated coefficients remain stable except for the effect of the proportion of international migrants in a locality on the probability of mailing a postcard, which has a $p$-value of only 12.6 percent (see table 2, column 7). The impact of migration to the United States is also still strongly positive and significant and that of migration to Portugal is statistically insignificant (see table 4, columns 8 and 9). The same results hold when disaggregated by current and return migration status: return migration from the United States is a powerful positive determinant of the demand for accountability, whereas current migration and return migration to Portugal are not statistically significant (see table 5, columns 8 and 9).

Overall, the most salient outcome when of using self-reported survey data instead of the postcard behavioral measure is that the magnitude of the estimated effects is much larger, an outcome that could be related to survey respondents' desire to conform to the perceived anticorruption message of the survey (conformity bias).

\section{Mechanics 3: Direct and Social Effects of Local Migration}

In summary, the evidence points to international emigration to countries with good governance (in particular, to the presence of return migrants) as promoting demand for political accountability in the origin country.

It is important to emphasize that the focus here is on the impact of localitylevel migration. The variable used, the proportion of international migrants within the household's spatial area of residence, can be understood as a proxy for the frequency of potential interactions between migrants and residents (who are not necessarily migrants and who do not necessarily have a return or current migrant in the household). The larger this proportion, the more likely such interactions will be and the more likely that people in the locality are more open to demanding accountability.

The effects of local migration are both direct and indirect. Return migrants, for instance, should have both a direct and an indirect impact on households in the locality. Current migrants can also have indirect effects through communications with their network of friends and family back home.

The empirical question left unanswered is that of the different magnitude of the direct and indirect effects identified at the local level. If additional data on migrant networks became available, this could be an important way forward in the literature.

\section{Concluding Remarks}

This article contributes to the understanding of a largely unmeasured but important potential effect of international emigration: its impact on institutional quality, a determinant of economic growth. 
The findings point to an overall positive impact of international emigration on the demand for improved political accountability in the country of origin. In particular, the results emphasize the importance of the migration destination country: the impacts are stronger for migration to countries with better governance. The impacts are also stronger for return migrants than for current migrants, who can only indirectly influence their relationship networks in the home country.

International emigration likely affects the supply side of domestic political institutions as well as the demand side, a part of the lively ongoing "brain drain" vs. "brain gain" debate. Total effects could presumably be negative if there were positive selection in current emigration flows and positive if skilled migrants return. This is an empirical question to be answered by future research.

\section{REFERENCES}

Acemoglu, Daron, Simon Johnson, and James A. Robinson. 2005. "Institutions as a Fundamental Cause of Long-Run Growth." In Handbook of Economic Growth, ed. Philippe Aghion, and Steven Durlauff. Amsterdam: North-Holland.

Alesina, Alberto, Arnaud Devleeschauwer, William Easterly, Sergio Kurlat, and Romain Wacziarg. 2003. "Fractionalization". Journal of Economic Growth 8 (2): 155-94.

Alesina, Alberto, and Paola Giuliano. 2009. "Family Ties and Political Participation.” IZA Discussion Paper 4150. Institute for the Study of Labor, Bonn.

Beine, Michel, Frederic Docquier, and Hillel Rapoport. 2008. “Brain Drain and LDCs' Growth: Winners and Losers". Economic Journal 118: 631-52.

Batista, Catia, Tara McIndoe-Calder, and Pedro C. Vicente. 2010. "Return Migration and Entrepreneurship in Mozambique". Trinity College, Dublin.

Batista, Catia, Aitor Lacuesta, and Pedro C. Vicente. Forthcoming. "Testing the 'Brain Gain' Hypothesis: Micro Evidence from Cape Verde." Journal of Development Economics.

Docquier, Frédéric, Elisabetta Lodigiani, Hillel Rapoport, and Maurice Schiff. 2010. “Emigration and the Quality of Home Country Institutions". Catholic University of Louvain, University of Luxembourg, Harvard University, and World Bank.

Docquier, Frédéric, and Abdeslam Marfouk. 2006. "International Migration by Education Attainment, 1990-2000." In International Migration, Brain Drain and Remittances, ed. Caglar Ozden, and Maurice Schiff. New York, NY: Palgrave Macmillan.

Downs, Anthony. 1957. An Economic Theory of Democracy. New York: Harper Collins.

Dustmann, Christian, and Oliver Kirchkamp. 2003. "Migration Duration and Activity Choice after Re-Migration”. Journal of Development Economics 67: 351-72.

Edwards, A., and M. Ureta. 2003. "International Migration, Remittances, and Schooling: Evidence from El Salvador.” Journal of Development Economics 72: 429-61.

Fidrmuc, Jan, and Orla Doyle. 2004. "Voice of the Diaspora: An Analysis of Migrant Voting Behaviour”. CEPR Discussion Paper 4619. Center for Economic and Policy Research, Washington, DC.

Gould, D. M. 1994. "Immigrant Links to the Home Country: Empirical Implications for U.S. Bilateral Trade Flows," Review of Economics and Statistics 76 (2): 302-16.

Freedom House. 2010. Freedom of the Press 2010. www.freedomhouse.org/template.cfm?page=16 
Heston, Alan, Robert Summers, and Bettina Aten. 2006. Penn World Table Version 6.2. Center for International Comparisons of Production, Income, and Prices at the University of Pennsylvania, Philadelphia.

Hirschman, Albert. 1970. Exit, Voice, and Loyalty: Responses to Decline in Firms, Organizations, and States. Cambridge, MA: Harvard University Press.

INE (Instituto Nacional de Estatistica). 2002. Recenseamento Geral da População e da Habitação. Cidade da Praia, Cabo Verde: INE.

—. 2004. Inquérito às Despesas e Receitas Familiares. Cidade da Praia, Cabo Verde: INE.

Iranzo, S., and G. Peri. 2009. "Migration and Trade: Theory with an Application to the Eastern-Western European Integration.” Journal of International Economics 79 (1): 1-19.

Javorcik, Beata, Çaglar Özden, Mariana Spatareanu, and Cristina Neagu. Forthcoming. “Migrant Networks and Foreign Direct Investment". Journal of Development Economics.

Kugler, Maurice, and Hillel Rapoport. 2007. "International Labor and Capital Flows: Complements or Substitutes?”. Economics Letters 92 (2): 155-62.

Li, Xiaoyang, and John McHale. 2009. "Emigrants and Institutions". University of Michigan, Ann Arbor, and National University of Ireland, Galway.

Merlo, Antonio. 2006. "Whither Political Economy? Theories, Facts, and Issues." In Advances in Economics and Econometrics, Theory, and Applications: Ninth World Congress of the Econometric Society, vol. I, ed. R. Blundell, W. Newey, and T. Persson. Cambridge, UK: Cambridge University Press.

Mesnard, Alice, and Martin Ravallion. 2006. "The Wealth Effect on New Business Startups in a Developing Economy.” Economica 73: 367-92.

Minier, Jenny. 2001. “Is Democracy a Normal Good?” Southern Economic Journal 67 (4): 996-1009.

Rauch, J., and Vitor Trindade. 2002. "Ethnic Chinese Networks in International Trade." Review of Economics and Statistics 84: 116-30.

Reporters without Borders. 2009. Press Freedom Index 2009. http://en.rsf.org/

Riker, William H., and Peter C. Ordeshook. 1968. "A Theory of the Calculus of Voting." American Political Science Review 62: 25-42.

Spilimbergo, Antonio. 2009. "Foreign Students and Democracy." American Economic Review 99 (1): 528-43.

Transparency International. 2009. Transparency International Annual Report 2009. www.transparency .org .

Tullock, Gordon. 1967. Toward a Mathematics of Politics. Ann Arbor: University of Michigan Press.

World Bank. 2006. World Development Indicators. Washington, DC: World Bank.

. 2011. Worldwide Governance Indicators. http://info.worldbank.org/governance/wgi/

Yang, Dean. 2008. "International Migration, Remittances, and Household Investment: Evidence from Philippine Migrants’ Exchange Rate Shocks.” The Economic Journal 118: 591-630. 